Journal of

Aquaculture Engineering and Fisheries Research

1(1): 45-48 (2015)

E-ISSN 2149-0236

doi: 10.3153/JAEFR15004

ORIGINAL ARTICLE/ORİJİNAL ÇALIŞMA

KISA MAKALE

\title{
PRELIMINARY REPORT ON GENETIC IMPROVEMENT OF Heterobranchus longifilis THROUGH INTRASPECIFIC HYBRIDIZATION OF DIFFERENT STRAINS FROM NIGERIA
}

\author{
Olabode OLUFEAGBA, Victor Tosin OKOMODA \\ Department of Fisheries and Aquaculture, University of Agriculture Makurdi, Nigeria
}

Received: 05.11.2013

Accepted: 02.12.2014

Published online: 11.12.2014
Corresponding author:

Victor Tosin OKOMODA, Department of Fisheries and Aquaculture, University of Agriculture Makurdi, Nigeria

E-mail: okomodavictor@yahoo.com

\begin{abstract}
:
Three strains of Heterobranchus longifilis were obtained from different ecological zones in Nigeria namely Nassarawa (NS); Kainji (KK) and Ajase Ipo, (SW). Six intra specific progenies were obtained from the cross of the three strains from the ecological zones, hatchability was highest $(94.2 \%)$ in KK x KK (Kainji strains); while the intra specific cross between KK $x$ NS had the highest $(80.0 \%)$ hatchability. General observation of the study point to the fact that intra specific crosses involving SW and NS male have better survival rates.
\end{abstract}

Keywords:

African catfish, Induced breeding, fertilization, Hatchability survival 


\section{Introduction}

H.longifilis is one of the most important catfishes for aquaculture business all over the world. Outside Africa, it is farmed in far Europe, China, Brazil and India (Huisman and Richter, 1987). There have been several attempts to improve its performance through hybridization, chromosome manipulation, improved feeding and water quality management (Aluko, 1998). Even though, hybrids of H.longifilis with species like C. gariepinus has been found to express positive heterosis, unfortunately, the hybrid has been found to be fertile. The use of these fertile hybrids as broodstocks for production of fingerlings has posed serious threat to the purity of our local clariid catfish species (Nwadukwe, 1995). Apart from this, most farmers use the hybrid for breeding and the result has been poor yield due to genetic factors. One major strategy in preventing regression in growth is genetic improvement through selective breeding. According to Gjedrem and Thodesen (2005), the application of selective breeding coupled with proper management has led to improvement in the productivity of fishes such as Atlantic salmon, trout and tilapia.

The aim of selection of culturable fish species apart from better growth and survival is to develop resistance in them to various adverse environmental factors especially to variation in the temperatures, decreased oxygen levels and fluctuation in the level of $\mathrm{pH}$. Through selection, a strong genetic base is provided to withstand these adverse situations. Cross breeding different strains of $H$. longifilis to select for better spawning performance, survival and on the long run growth has a great potential in improving this Aquaculture candidate which is currently limited by poor growth and high cost of production. Therefore, the aim of this work is to carry out directional selection to better spawning performance and survival of H.longifilis.

\section{Materials and Methods}

\section{Broodstock Collection}

Broodstock of $H$. longifilis were collected from three (3) ecological zones of Nigeria, (i) Kainji within the Kaduna river basin hydrological zone in the guinea savannah (KK) (ii) Nasarawa within the north central savannah belt (NS) and (iii) Ajase Ipo within the uppermost fringe of the rain forest Osun river basin (SW).The broodstocks were transported alive to National Institute for Freshwater Fisheries Research, New Bussa and acclimatized in the outdoor concrete tanks. They were fed with artificially prepared fish feed consisting of $40 \%$ crude protein diet.

\section{Injection and fertilization technique}

Healthy breeders were removed from the concrete tanks by drag net. Brood fish were injected with Ovaprim ${ }^{\circledR}$ hormone at a dose of $0.5 \mathrm{~mL}$ per $\mathrm{kg}$. Latency period was known in the females when upon slight pressure on the abdomen, eggs freely ran out in a jet. The males were sacrificed and testes removed and kept in a Petridish. Milt collected was diluted with four fold volume of milt by saline $(0.9 \% \mathrm{NaCl}$ solution) and eggs were collected in a dry Petridish. Fertilization was carried out by mixing milt with eggs aided by feather in order to ensure maximum fertilization.

\section{Parental and intraspecific breeding experiment}

The following genetic mating combinations (Female $\mathrm{x}$ Male) were generated during the experiment

(a) Parental mating groups

1. KK $x$ KK

2. $\mathrm{SW} \times \mathrm{SW}$

3. NS $x$ NS

(b) Intraspecific crosses

4. KK x SW

5. KK $x$ NS

6. SW $\mathrm{x} \mathrm{KK}$

7. SW x NS

8. NS $x$ KK

9. NS $\times$ SW

\section{Incubation of fertilized eggs}

A total of 18 glass aquaria tanks $(60 \times 30 \times$ $30 \mathrm{~cm}^{3}$ ) were used in the study. Kakaban (egg collector) was arranged in each tank after which clean biologically filtered water up to one-third level of each tank was introduced. The water in each tank was constantly aerated using aerator. Fertilized eggs were poured directly on the Kakaban that served as egg collector. Water quality parameters (temperature, $\mathrm{pH}$, dissolved oxygen) 
Journal abbreviation: J Aquacult Eng Fish Res

were monitored. Analysis of the hatchability performance was carried out using multivariance general linear model at 0.05 alpha level.

\section{Determination of percentage hatchability and fry management}

After hatching, the kakabans were removed in all the 24 aquaria tanks. Direct counting of unhatched eggs attached to kakabans and those on the floor of the aquaria was done directly. Hatched eggs were determined on the basis of the percentage of unhatched eggs. The eggs used for fertilization were $200( \pm 10)$ in each of the treatments.

Fry yolk sac was absorbed in about three days after which feeding with live freshwater zooplankton mainly Moina micrura commenced. Feeding was done ad libitum. Left-over dead zooplanktons were siphoned from the base of the tanks every day before introducing new ration of zooplankton. Feeding was done twice daily, i.e. morning and evening.

\section{Results and Discussion}

After 23 hours of incubation of eggs, hatching started in all the treatments. The water quality was at optimum level (temperature $26^{\circ} \mathrm{C}, \mathrm{pH}=$ 7.1 , dissolved oxygen $=5.0 \mathrm{mg} / \mathrm{L}$ ). Among the parentals, the best hatchability was observed with the Kainji broodstocks (94.2\%), while the least was recorded in the collection from Nassarawa (36.3\%) (Table 1). Among the six Intraspecific crossbreeds, the best performance was observed in the cross between female $\mathrm{KK}$ and male NS $(80.0 \%)$, and the least performance was observed in the cross between NS x SW (41.3\%). However the trend in hatchability seems to favour any cross involving female KK. The maternal effect which is inherent in the mitochondrion deoxyribonucleic acid is suspected to be the factor responsible for this. This result of hatchability of pure strain crosses agrees with previous study by Haniffa and Sridhar (2002). Nwokoye et al. (2007) reported percentage fertilization of $98.31 \%$ and $96.01 \%$ for Heterobranchus bidorsalis induced with synthetic hormone (ovaprim) and homoplastic hormone (pituitary of Heterobranchus bidorsalis) respectively. The slight difference in percentage fertilization obtained in this study and the previous ones might be due to difference in experimental design

The six experimental crosses had lower hatchability and survival (Table 1) when compared with the parental crosses. Similar result was reported by Salami et al (1993) in their cross involving $C$. gariepinus and $H$. bidorsalis and the various reported works of Olufeagba (1999), Aluko and Ali, (2001).The values of survival is small when compared with the result of the study by Nwokoye et al. (2007) who reported $99.88 \%$ survival rate for Heterobranchus bidorsalis induced with ovaprim and $99.61 \%$ for those induced with pituitary of Heterobranchus bidorsalis. However, De Graaf et al. (1995) reported a survival rate of $41.5 \%$ for C. gariepinus reared under a medium stocking density for a short duration in protected tanks. This observed difference might have been caused by water quality management, rearing condition, species and strain variation.

Table 1. Mean hatchability performance in parental and experimental crosses in $\mathrm{H}$. longifilis collected from three ecological zones in Nigeria

\begin{tabular}{ccccr}
\hline TREATEMENT & NO OF EGGS & NO OF HATCHLINGS & \% HATCHABILITY & \% SURVIVAL \\
\hline KK x KK & $200 \pm 0.20$ & $188 \pm 0.23^{\mathrm{a}}$ & $94.2 \pm 0.01^{\mathrm{a}}$ & $63.8 \pm 0.12^{\mathrm{c}}$ \\
SW x SW & $200 \pm 0.10$ & $133 \pm 0.11^{\mathrm{c}}$ & $66.6 \pm 0.01^{\mathrm{c}}$ & $76.6 \pm 0.11^{\mathrm{b}}$ \\
NS x NS & $200 \pm 0.01$ & $72 \pm 0.12^{\mathrm{e}}$ & $36.3 \pm 0.02^{\mathrm{f}}$ & $62.5 \pm 0.00^{\mathrm{c}}$ \\
KK x SW & $200 \pm 0.1$ & $96 \pm 1.20^{\mathrm{d}}$ & $48.0 \pm 0.12^{\mathrm{c}}$ & $10.41 \pm 0.02^{\mathrm{d}^{*}}$ \\
KK x NS & $200 \pm 0.11$ & $160 \pm 1.10^{\mathrm{b}}$ & $80.0 \pm 0.11^{\mathrm{b}}$ & $9.38 \pm 0.02^{\mathrm{d}^{*}}$ \\
SW x KK & $200 \pm 0.13$ & $126 \pm 0.02^{\mathrm{c}}$ & $63.8 \pm 0.02^{\mathrm{c}}$ & $87.3 \pm 0.12^{\mathrm{a}}$ \\
SW x NS & $200 \pm 0.10$ & $88 \pm 0.11^{\mathrm{d}}$ & $43.9 \pm 0.02^{\mathrm{d}}$ & $75.0 \pm 0.03^{\mathrm{b}}$ \\
NS x KK & $200 \pm 0.21$ & $89 \pm 1.23^{\mathrm{d}}$ & $44.5 \pm 0.11^{\mathrm{d}}$ & $85.4 \pm 0.01^{\mathrm{a}}$ \\
NS x SW & $200 \pm 0.2$ & $83 \pm 1.01^{\mathrm{de}}$ & $41.3 \pm 0.02^{\mathrm{e}}$ & $90.4 \pm 0.11^{\mathrm{a}}$ \\
\hline P-Value & 0.123 & 0.001 & 0.001 & 0.001 \\
\hline
\end{tabular}

Mean in the same column with different superscript differ significantly $(\mathrm{P}<0.05)$.

*Mortality of fish due to water shortage. 
The present result of high hatching in both the parental and crossbreed crosses agrees with the results of other reports (Olufeagba1999, Aluko and Ali, 2001). The period incubation i.e time between fertilization and hatching varies. While Olufeagba (1999) reported 23.1hours, hatching occurred $24.8 \mathrm{hrs}$ in this experiment. This could be attributed to variation in the laboratory temperature that affects cellular activities. The fry were viable and no abnormality was observed. Viable intra specific (selective breeding) produced under laboratory condition will help to improve performance of fish, progenies are currently observed for growth and heterosis.

The chromosome of the different strains revealed high level of similarity which made crossbreeding among the ecotypes very successful in all the crosses. The behavior of the chromosome is a good indicator about the success level of the cross breeds. The Karyotype of $H$. longifilis $(2 n=50)$ has been reported (Olufeagba, 1999; Olufeagba et al. 1999).

\section{Conclusion}

The fry has been transferred into outdoor tanks and are being raised to adult size to enable selection for the production of the $\mathrm{F}_{2}$ generation. As soon as the results for frequency of early maturing females, growth rate are available, the strains will be ranked according to their combined breeding values. All fish from the 5 top ranked in different strains will be pre-selected and restocked.

Final selection of broodstock to produce the next generation in the breeding program will be based on early sexually maturing female and body weight of the individual.

\section{References}

Aluko, P.O. (1998): growth characteristics of the parental, F1, F2 and backcross generation of the hybrids between Heterobranchus longifilis and Clarias anguillaris. West African Journal of Biological Sciences, 8: 16-21.

De Graaf, G.J., Galemoni, F., Banzoussi, B. (1995): The Artificial Reproduction and Fingerlinging Production of the African Catfish, Clarias gariepinus (Burchell, 1822 ) in protected and unprotected ponds. Aquaculture Research, 26: 233-242.
Gjedrem T.G., Thodesen, J. (2005): Selection and Breeding programs in Aquaculture. $1^{\text {st }} \mathrm{Ed}$. New York. Springer, p 364.

Haniffa, M.A.K., Sridhar, S. (2002): Induced spawning of spotted murrel (Channa punctatus) and catfish (Heterebranchus fossils) using human chorionic gonadotropin and synthetic hormone (ovaprim). Veterinary Archive, 72(1): 51-56.

Huisman, E.A., Richter, C.J. (1987): Reproduction, growth, health control and Aquacultural potential of the African catfish, Clarias gariepinus (Burchell, 1822). Aquaculture, 68: 1-14.

Nwadukwe, F.O. (1995): Hatchery propagation of five hybrid groups by artificial Hybridizations of Clarias gariepinus (B) and Heterobranchus longifilis (Val) (Clariidae) using dry powdered carp pituitary hormone. Journal of Aquaculture in the Tropics, 10:1-11

Nwokoye, C.O., Nwuba, L.A., Eyo, J.E. (2007): Induced propagation of African clariid catfish, Heterobranchus bidorsalis (Geoffrey Saint Hillarie, 1809) using synthetic and homoplastic hormones. African Journal of Biotechnology, 6(23): 2687-2693.

Olufeagba S.O. (1999): Induced triploid Heterobranchus longifilis and its Aquacultural potentials (Val. 1840) (Family: Clariidae). $\mathrm{Ph}$. D. Thesis submitted to Biological Science Department, University of Ilorin. Pp 164

Olufeagba, S.O., Aluko P.P., Omotosho, J.S. (1999): Karyomorphology of the African catfish, Heterobranchus longifilis (Val). Nigerian Journal of Genetics, 4: 23-29

Salami, A.A., Fagbenro, O.A., Sydenham, D.H.J. (1993): The production and Growth of Clarrid Catfish Hybrids in concrete tanks. The Israeli $J$ of Aquaculture-Bamidgeh, 45(1): 18-25. 